\title{
Preparation of neuroprotective condensed 1,4-benzoxazepines by regio- and diastereoselective domino Knoevenagel-[1,5]-hydride shift cyclization reaction
}

\author{
László Tóth ${ }^{1,2}$, Yan Fu ${ }^{3}$, Hai Yan Zhang ${ }^{3}$, Attila Mándi ${ }^{2}$, Katalin E. Kövér ${ }^{4}$, \\ Tünde-Zita Illyés ${ }^{2}$, Attila Kiss-Szikszai ${ }^{2}$, Balázs Balogh ${ }^{1}$, Tibor Kurtán ${ }^{2,5}$, Sándor Antus ${ }^{*}$ \\ and Péter Mátyus*1
}

\section{Letter}

\section{Address:}

${ }^{1}$ Department of Organic Chemistry, Semmelweis University, Högyes u. 7., 1092 Budapest, Hungary, Fax: +36 1 217-0851, ${ }^{2}$ Department of Organic Chemistry, University of Debrecen, Debrecen, P. O. Box 20, 4010 Debrecen, Hungary, ${ }^{3}$ CAS Key Laboratory of Receptor Research, Shanghai Institute of Materia Medica, Chinese Academy of Sciences, 555 Zu Chong Zhi Road, Zhang Jiang Hi-Tech Park, Shanghai 201203, PR China, ${ }^{4}$ Department of Inorganic and Analytical Chemistry, University of Debrecen, H-4010 Debrecen, Hungary and

${ }^{5}$ Porfirin Ltd., Mikszáth K. u. 7. III/3, 4032 Debrecen, Hungary

Email:

Sándor Antus* - antus.sandor@science.unideb.hu; Péter Mátyus* peter.matyus@szerves.sote.hu

* Corresponding author

\section{Keywords:}

1,4-benzoxazepine; diastereoselective domino

Knoevenagel-[1,5]-hydride shift cyclization; neuroprotective;

tert-amino effect; TDDFT-ECD calculation

\author{
Beilstein J. Org. Chem. 2014, 10, 2594-2602. \\ doi:10.3762/bjoc. 10.272 \\ Received: 28 April 2014 \\ Accepted: 16 October 2014 \\ Published: 06 November 2014 \\ Associate Editor: J. Aubé \\ C 2014 Tóth et al; licensee Beilstein-Institut. \\ License and terms: see end of document.
}

\begin{abstract}
Condensed $O, N$-heterocycles containing tetrahydro-1,4-benzoxazepine and tetrahydroquinoline moieties were prepared by a regio- and diastereoselective domino Knoevenagel-[1,5]-hydride shift cyclization reaction of a 4-aryl-2-phenyl-1,4-benzoxazepine derivative obtained from flavanone. The relative configuration of products were determined by the correlation of ${ }^{3} J_{\mathrm{H}, \mathrm{H}}$ coupling data with the geometry of major conformers accessed by DFT conformational analysis. Separated enantiomers of the products were characterized by HPLC-ECD data, which allowed their configurational assignment on the basis of TDDFT-ECD calculation of the solution conformers. Two compounds showed neuroprotective activities against hydrogen peroxide $\left(\mathrm{H}_{2} \mathrm{O}_{2}\right)$ or $\beta$-amyloid $25-35$ $\left(\mathrm{A} \beta_{25-35}\right.$ )-induced cellular injuries in human neuroblastoma SH-SY5Y cells in the range of those of positive controls.
\end{abstract}




\section{Introduction}

The 1,4-benzoxazepine structural unit and its analogues are found in several pharmacologically active derivatives such as the selective 5-HT $1 \mathrm{~A}$ agonist SUN 8399 (1) [1], the neuroprotective piclozotan (2) $[2,3]$, the antihistaminic rocastine $(3)$ $[4,5]$, and the antihelmintic 4 [6] (Figure 1).

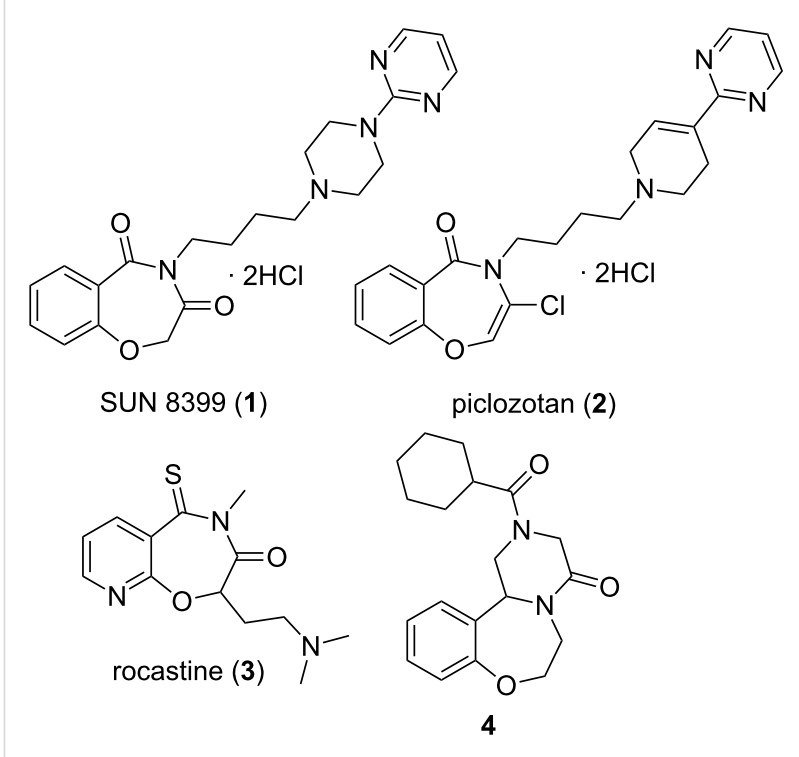

Figure 1: Pharmacologically active derivatives 1-4 containing the 1,4benzoxazepine moiety or its analogue.
We report herein the preparation of two neuroprotective condensed 2-phenyl-1,4-benzoxazepines rac-7a,b through the diastereoselective domino Knoevenagel-1,5-hydride shift cyclization reaction $r a c-5 \rightarrow r a c-7 a, b$ from the readily available 4-aryl-2-phenyl-1,4-benzoxazepine derivative, rac-5 (Scheme 1).

Ring-closure transformations involving $\mathrm{C}\left(\mathrm{sp}^{3}\right)-\mathrm{H}$ bond functionalization in an internal redox process, particularly involving $\mathrm{C}-\mathrm{H}$ bonds in $\alpha$-position to a tertiary amine nitrogen atom, has attracted considerable attention due to its synthetic potential [7-11]. The intramolecular "tert-amino effect" induced cyclization consists in (1) the cleavage of the $\mathrm{C}\left(\mathrm{sp}^{3}\right)-\mathrm{H}$ bond $\alpha$ to a tertiary amine nitrogen through [1,5]-hydride shift $($ rac $-\mathbf{6} \rightarrow \mathbf{A})$ (Scheme 1) to afford the zwitterionic intermediate $\mathbf{A}$ and (2) subsequent 6-endo cyclization $(\mathbf{A} \rightarrow r a c-7 \mathbf{a}, \mathbf{b})$.

The stereoselective version of "tert-amino effect" induced cyclization using chiral metal-catalyzed [12-15] or organocatalytic $[16,17]$ reactions and the mechanism of the stereospecific hydride transfer have been recently studied by several research groups. The synthetic potential of the diastereoselective domino Knoevenagel-[1,5]-hydride shift cyclization reaction was exploited in our present work for the preparation of condensed $O, N$-heterocycles with the 1,2,8,9-tetrahydro- $7 \mathrm{~b} H$ quinolino[1,2- $d][1,4]$ benzoxazepine skeleton, the neuroprotec-<smiles>CO[C@H]1CN(c2ccc([N+](=O)[O-])cc2C=O)C[C@@H](c2ccccc2)O[C@@H]2C=CC=C[C@H]21</smiles>

rac-5

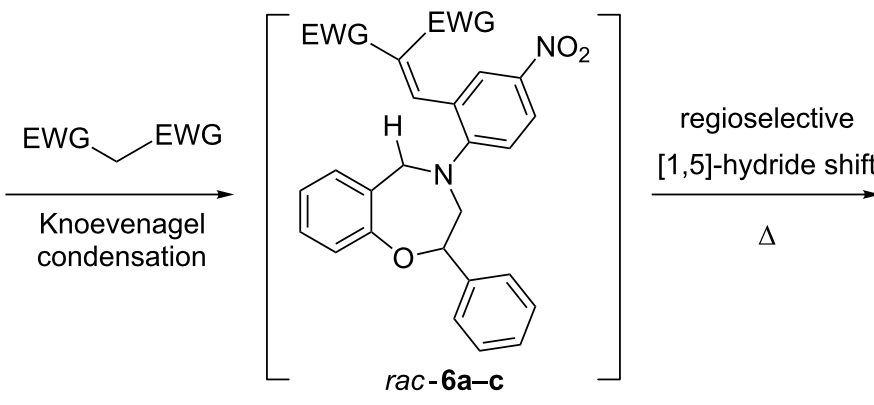<smiles>CCC(C)(C)C1(C)Cc2cc([N+](=O)[O-])ccc2N2C[C@H](c3ccccc3)Oc3ccccc3[C@]21C</smiles>

rac-7a,b 
tive activities of which were tested against hydrogen peroxide $\left(\mathrm{H}_{2} \mathrm{O}_{2}\right)$, Alzheimer's amyloid $\beta$-peptide fragment $\mathrm{A} \beta_{25-35}$ and oxygen-glucose deprivation (OGD)-induced neurotoxicity in human neuroblastoma SH-SY5Y cells.

\section{Results and Discussion}

The starting material 4-aryl-2-phenyl-1,4-benzoxazepine ( $r a c-$ 5) for the domino Knoevenagel-[1,5]-hydride shift cyclization reaction was prepared from $r a c$-flavanone ( $\mathrm{rac}-\mathbf{8})$ in four steps (Scheme 2).

The Schmidt reaction of $\mathrm{rac}-\mathbf{8}$ was carried out according to the procedure of Litkey and Patonay [18] affording the racemic 3,4dihydro-2-phenyl-1,4-benzoxazepine-5-one ( $r a c-9)$ with high regioselectivity, which was reduced to $(\mathrm{rac})-\mathbf{1 0}$ with LAH in dry THF. In the following step, the $N$-arylation of $\mathrm{rac}-\mathbf{1 0}$ was performed through a nucleophilic aromatic substitution by using 2-fluoro-5-nitrobenzaldehyde (11b) to give rac-5 containing a tertiary arylamine nitrogen in $71 \%$ yield. With the 2 -chloro-5nitrobenzaldehyde reagent, only $3 \%$ yield for $r a c-5$ could be achieved. Subsequently rac-5 was reacted with 1,3-dimethylbarbituric acid (12), Meldrum's acid (13) and malononitrile (14) all containing active methylene groups, which initiated a domino reaction (Scheme 2). The Knoevenagel reaction of the formyl group in rac-5 and the active methylene groups of 12-14 afforded the intermediates rac-6a-c (Scheme 1), which underwent regioselective [1,5]-hydride shift with participation of the benzylic hydrogen to result in the zwitterionic iminium ion intermediates $\mathbf{A}$. The 6-endo cyclization of this intermediate gave rac-trans-7a,b with high diastereoselectivity, which was governed by the $\mathrm{C}-2$ chirality center of intermediate $\mathbf{A}$. In contrast to the domino reaction with 1,3-dimethylbarbituric acid (12) and Meldrum's acid (13), the reaction with malonitrile (14) stopped at the stage of the Knoevenagel product $\mathrm{rac}-\mathbf{7} \mathbf{c}$ with $\mathrm{MgSO}_{4}$ in $\mathrm{CHCl}_{3}$ and further cyclization did not occur when heated in DMSO at $150{ }^{\circ} \mathrm{C}$ or refluxed in $n$-butanol.

The NMR data of $7 \mathbf{a}, \mathbf{b}$ clearly indicated that they were single diastereomers and the determination of the relative configuration was carried out by the correlation of NMR data and DFT<smiles>CC(C)CC(=O)Oc1cccc2c1C(=O)NCC(c1ccccc1)O2</smiles>

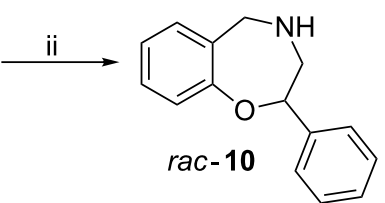<smiles>CN1C(=O)N(C)N2C[C@@H](c3ccccc3)Oc3ccc([N+](=O)[O-])cc3C(CC(C)(C)C)(Oc3ccccc32)C1=O</smiles><smiles></smiles><smiles>C=C(C1CN(c2ccc([N+](=O)[O-])cc2C=O)Cc2ccccc2O1)C(F)(F)F</smiles><smiles>[X]c1ccc([N+](=O)[O-])cc1C=O</smiles>

11a: $\mathrm{X}=\mathrm{Cl}(3 \%)$

11b: $X=F(71 \%)$ rac-trans-7a

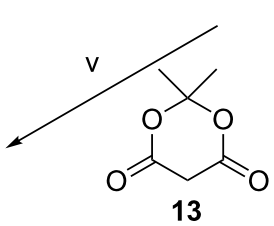

(S)

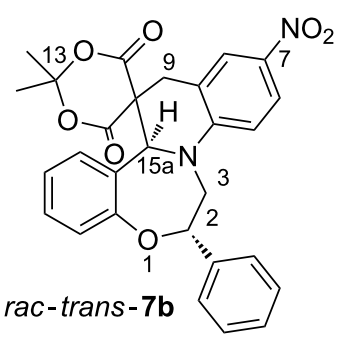

(S)

rac-5

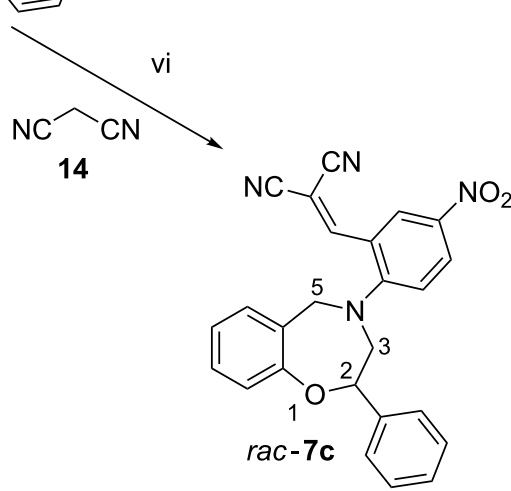


conformational analysis of cis- and trans-7a,b (Figure 2 and Figure 3).

a)

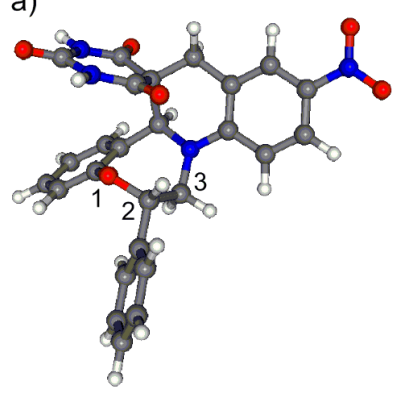

b)

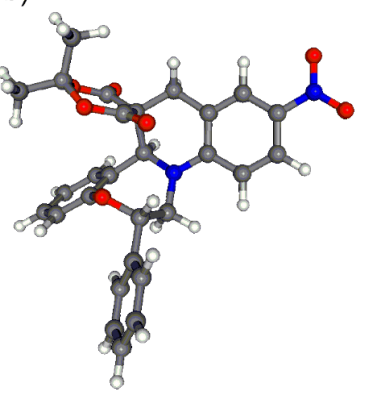

Figure 2: Lowest-energy conformers of a) trans-(2S,15aS)-7a $(>99.9 \%)$ with the replacement of the $N$-methyl groups by hydrogen atoms; b) trans-(2S,15aS)-7b (97.9\%) obtained by the B3LYP/6$31 \mathrm{G}(\mathrm{d})$ reoptimization of the initial MMFF conformers. Boltzmann weights for the same conformers in the PCM calculations are $99.8 \%$ and $95.8 \%$, respectively.
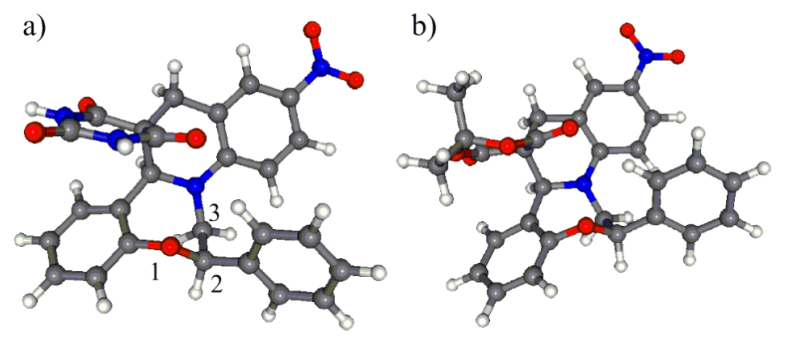

Figure 3: Lowest-energy conformers of a) cis-(2R,15aS)-7a (99.4\%) with the replacement of the $\mathrm{N}$-methyl groups by hydrogen atoms; b) cis-(2R,15aS)-7b (84.5\%) obtained by the B3LYP/6-31G(d) reoptimization of the initial MMFF conformers. Boltzmann weights for the same conformers in the PCM calculations are $97.7 \%$ and $82.5 \%$, respectively.

Although the hydrogens $2-\mathrm{H}$ and $15 \mathrm{a}-\mathrm{H}$ of cis-7a,b are expected to point toward the same side of the molecules, the analysis of the computed solution conformers of cis-7a,, $\mathbf{b}$ revealed that the orientation and distance $(>4.6 \AA)$ of these methine protons (Figure 3) does not allow for the detection of their NOE contact, rendering the NOE-based assignment of the relative configuration ambiguous. Similarly, no NOE correlation is expected between $2-\mathrm{H}$ and $15 \mathrm{a}-\mathrm{H}$ of trans-7a,b, which was also evident from the structures of their computed lowest-energy conformers (Figure 2). Accordingly, no characteristic NOE was observed between these methine protons for $\mathbf{7 a}, \mathbf{b}$, which did not help for the assignment of the relative configuration. However, in the computed solution conformers of cis-7a, $\mathbf{b}$, the oxazepine ring adopts a twist boat conformation with axial 2-H showing gauche orientation with adjacent $3-\mathrm{H}$ protons (e.g., $\omega_{2-\mathrm{Hax}, \mathrm{C}-2, \mathrm{C}-3,3-\mathrm{Hax}} \approx 36.2^{\circ}, \omega_{2-\mathrm{Hax}, \mathrm{C}-2, \mathrm{C}-3,3-\mathrm{Heq}} \approx-79.2^{\circ}$ in $\left.7 \mathbf{a}\right)$, suggesting small ${ }^{3} J_{2-\mathrm{H}, 3-\mathrm{H}}$ couplings.

Whereas in the computed solution conformers of trans-7a,b (Figure 2), the oxazepine ring adopts a boat conformation showing a trans-diaxial relationship with the adjacent $3-\mathrm{H}_{\mathrm{ax}}$. In accordance with the calculations, the measured values of the ${ }^{3} J_{2-\mathrm{Hax}, 3-\mathrm{H}}(11.5$ and $3.2 \mathrm{~Hz})$ corroborate that the couplings between $2-\mathrm{H}_{\mathrm{ax}}$ and 3 -Hs derive from trans-diaxial $\left(\omega_{2-\mathrm{Hax}, \mathrm{C}-2, \mathrm{C}-3,3-\mathrm{Hax}} \approx 180^{\circ}\right)$ and gauche $\left(\omega_{2-\mathrm{Hax}, \mathrm{C}-2, \mathrm{C}-3,3-\mathrm{Heq}} \approx\right.$ $60^{\circ}$ ) orientations, which is only feasible with the trans relative configuration of $\mathbf{7 a}, \mathbf{b}$. Thus in the course of the cyclization, the attack of the carbanion to the iminium carbon of intermediate $\mathbf{A}$ occurred with trans-diastereoselectivity to the C-2 phenyl group. The formation of the diastereomeric cis-7a, $\mathbf{b}$ could not be detected.

The chiral HPLC analysis of the products $7 \mathbf{a}, \mathbf{b}$ also confirmed that the reaction took place diastereoselectively and enantiomers of trans-7a,b were separated on a Chiralpak IA column using hexane/dichloromethane as eluent and online HPLC-ECD spectra of the separated enantiomers were recorded. Due to their similar chromophoric system, the HPLC-ECD spectra of $7 \mathbf{a}$ and $\mathbf{7 b}$ were quite similar. The first-eluting enantiomer of $\mathbf{7 a}$ had an intense broad positive Cotton effect (CE) at $378 \mathrm{~nm}$, negative ones at 314, 305, $272 \mathrm{~nm}$ and positive ones at 284, 279 and $224 \mathrm{~nm}$ (Figure 4a).

The HPLC-ECD spectrum of the first-eluting enantiomer of $\mathbf{7 b}$ showed similar ECD pattern with somewhat different shape and intensities in the 290-240 $\mathrm{nm}$ range (Figure 4b). TDDFT-ECD calculation was proved an efficient method to determine the absolute configuration of separated stereoisomers of bioactive synthetic [19] and natural derivatives [20,21] on the basis of their HPLC-ECD spectra.

For the configurational assignment of the separated enantiomers, TDDFT-ECD calculations were carried out on the solution conformers of $(2 S, 15 \mathrm{a} S)-7 \mathbf{d}$ ( $N$-methyl groups were replaced by hydrogens for the calculation) and (2S,15aS)-7b and computed ECD curves were compared with the measured HPLC-ECD ones of the separated enantiomers of trans-7a,b (Figure $4 \mathrm{a}$ and Figure $4 \mathrm{~b}$ ). The computed TDDFT-ECD spectra of $(2 S, 15 \mathrm{a} S)-7 \mathbf{d}$ and $(2 S, 15 \mathrm{a} S)-7 \mathbf{b}$ gave good agreement with the experimental HPLC-ECD spectra of the second-eluting enantiomers (Figure 4a,b), which allowed determining the absolute configuration of their second-eluting enantiomers (negative CEs at 370 and $371 \mathrm{~nm}$, respectively) as $(2 S, 15 \mathrm{a} S)$. The good agreement between the experimental HPLC-ECD and 
a)

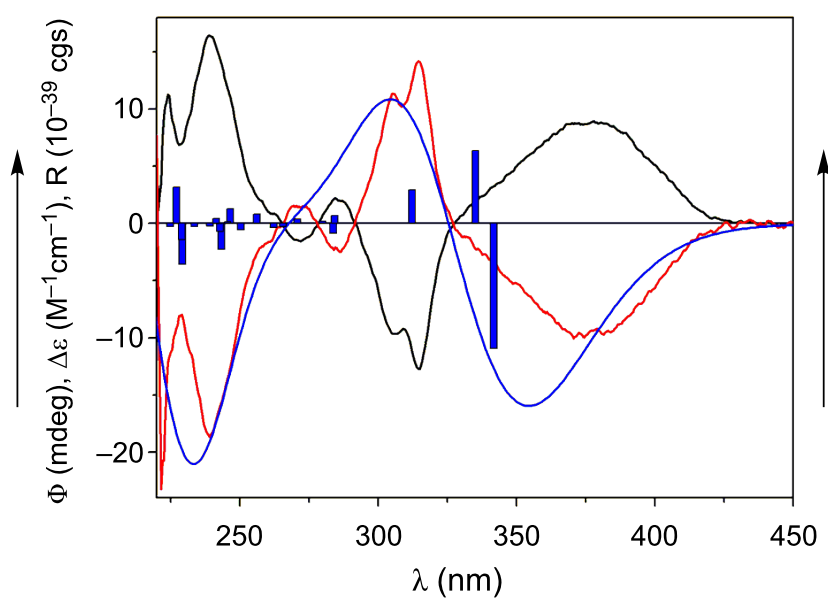

b)

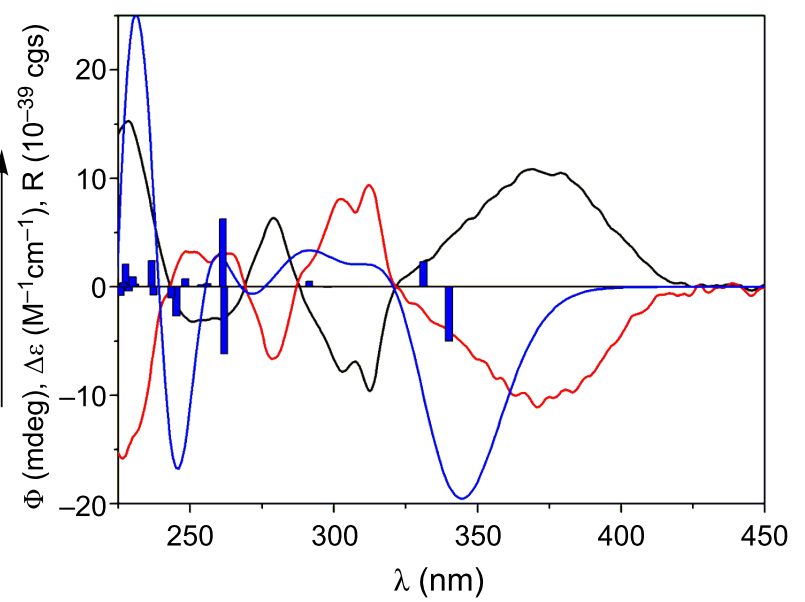

c)<smiles>C[C@H]1Oc2ccccc2CC12C(=O)NC(=O)CN1C[C@@H](c3ccccc3)Oc3ccccc3CC12</smiles>

$(2 S, 15 a S)-7 d$

Figure 4: HPLC-ECD spectra of the first-eluting (black curve) and second-eluting (red curve) enantiomers of a) trans-7a, and b) trans-7b compared with the computed ECD spectra of the gas-phase optimized conformers $(>1 \%)$ of model compound $(2 S, 15 a S)-7 d$ ( 1 conformer, B3LYP/TZVP) and (2S,15aS)-7b (2 conformers, BH\&HLYP/TZVP). Bars represent the computed rotational strength values (R/8) of the lowest-energy conformer. c) Structure of the $(2 S, 15 a S)-7 \mathbf{d}$ model compound of trans-7a used for the conformational analysis and ECD calculations.

computed ECD spectra of 7a,b not only allowed the configurational assignment of their separated enantiomers but also confirmed independently the trans-diastereoselectivity of the cyclization.

The neuroprotective activities of $\mathrm{rac}-\mathbf{7} \mathbf{a}, \mathbf{b}$ and $\mathrm{rac}-\mathbf{5}$ were tested against hydrogen peroxide $\left(\mathrm{H}_{2} \mathrm{O}_{2}\right), \beta$-amyloid-25-35 $\left(\mathrm{A} \beta_{25-35}\right)$ and oxygen-glucose deprivation (OGD)-induced neurotoxicity in human neuroblastoma SH-SY5Y cells [22]. The preliminary screenings showed that $\mathrm{rac}-\mathbf{7 a}$ at $10 \mu \mathrm{M}$ concentration displayed neuroprotective activity against $\mathrm{H}_{2} \mathrm{O}_{2}$-induced cellular injuries in human neuroblastoma SH-SY5Y cells with $16.4 \%$ increase in cell viability (Figure 5), while $10 \mu \mathrm{M}$ of rac$7 \mathbf{b}$ increased cell viability in $\mathrm{A} \beta_{25-35}$-induced neurotoxicity by $22.8 \%$ (Figure 6).

The positive controls with $N$-L-acetylcysteine (NAC) [23] and epigallocatechin gallate (EGCG) [24] increased cell viability by $17.3 \%$ and $22.4 \%$ in $\mathrm{H}_{2} \mathrm{O}_{2}$ and $\mathrm{A} \beta_{25-35}$ model, respectively. Compounds $\mathrm{rac}-\mathbf{7 a}, \mathbf{b}$ and $\mathrm{rac}-\mathbf{5}$ did not show acetylcholinesterase inhibitory effect.

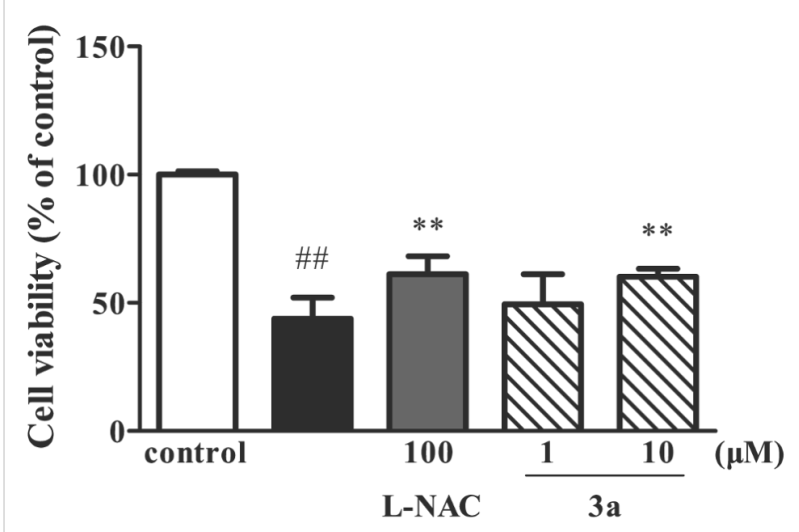

Hydrogen Peroxide $(100 \mu \mathrm{M})$

Figure 5: Protective effect of compound $7 \mathrm{a}$ on hydrogen peroxideinduced neurotoxicity in SH-SY5Y cells. \# P $<0.01$ vs control group, ${ }^{* *} P<0.01$ vs hydrogen peroxide group.

\section{Conclusion}

Regioselective domino Knoevenagel-[1,5]-hydride shift cyclization reactions of a 4-aryl-2-phenyl-1,4-benzoxazepine 


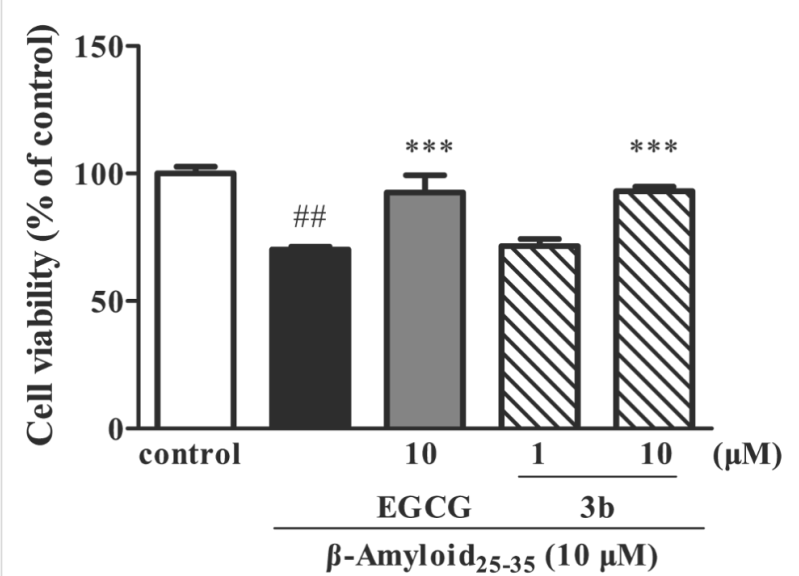

Figure 6: Protective effect of compound $7 \mathbf{b}$ on $\beta$-amyloid $25-35$-induced neurotoxicity in SH-SY5Y cells. ${ }^{\# \#} \mathrm{P}<0.01$ vs control group, ${ }^{* *} \mathrm{P}<0.01$ vs $\beta$-amyloid $25-35$ group.

derivative afforded three condensed $O, N$-heterocycles containing tetrahydro-1,4-benzoxazepine and tetrahydroquinoline moieties. trans-Diastereoselectivity of the cyclizations was determined by the correlation of ${ }^{3} J_{\mathrm{H}, \mathrm{H}}$ coupling constants with the geometry of the computed conformers, while $(2 R, 15 \mathrm{a} R)$ absolute configurations of $\mathbf{7 a}, \mathbf{b}$ were assigned to the separated enantiomers showing positive $\mathrm{CE}$ for the lowest-energy ECD transition by the comparison of the experimental HPLC-ECD spectra with those obtained by the TDDFT-ECD calculations of the solution conformers. Compound 7a showed neuroprotective activity against hydrogen peroxide $\left(\mathrm{H}_{2} \mathrm{O}_{2}\right)$, while $\mathbf{7 b}$ against $\beta$-amyloid $25-35\left(\mathrm{~A} \beta_{25-35}\right)$-induced cellular injuries in human neuroblastoma SH-SY5Y cells with $16.4 \%$ and $22.8 \%$ increase in cell viability at $10 \mu \mathrm{M}$ concentrations, respectively.

\section{Experimental}

Melting points were determined on a Kofler hot-stage apparatus and are uncorrected. The NMR spectra were recorded on Bruker-AMX $500\left({ }^{1} \mathrm{H}: 500 \mathrm{MHz} ;{ }^{13} \mathrm{C}: 125 \mathrm{MHz}\right)$ and Bruker Avance II $400\left({ }^{1} \mathrm{H}: 400 \mathrm{MHz} ;{ }^{13} \mathrm{C}: 100 \mathrm{MHz}\right)$ spectrometers using TMS as internal standard. Chemical shifts were reported as $\delta$ in ppm and ${ }^{3} J_{\mathrm{H}, \mathrm{H}}$ coupling constants in Hz. Chiral HPLC separation of 7a,b were performed on a Jasco HPLC system with Chiralpak IA column $(5 \mu \mathrm{m}, 150 \times 4.6 \mathrm{~mm}$, hexane/ dichloromethane 80:20 or 70:30 eluents, $1 \mathrm{~mL} \mathrm{~min}^{-1}$ flow rate) and HPLC-ECD spectra were recorded in stopped-flow mode on a JASCO J-810 electronic circular dichroism spectropolarimeter equipped with a $10 \mathrm{~mm}$ HPLC flow cell. ECD ellipticity $(\Phi)$ values were not corrected for concentration. For an HPLC-ECD spectrum, three consecutive scans were recorded and averaged with $2 \mathrm{~nm}$ bandwidth, $1 \mathrm{~s}$ response, and standard sensitivity. The HPLC-ECD spectrum of the eluent recorded in the same way was used as background. The concentration of the injected sample was set so that the HT value did not exceed $500 \mathrm{~V}$ in the HT channel down to $230 \mathrm{~nm}$. IR spectra were recorded on a JASCO FTIR-4100 spectrometer and absorption bands are presented as wavenumber in $\mathrm{cm}^{-1}$. Electrospay Quadrupole Time-of-Flight HRMS measurements were performed with a MicroTOF-Q type QqTOF MS instrument equipped with an ESI source from Bruker (Bruker Daltoniks, Bremen, Germany). Elementary analysis was carried with a Vario Micro V1.9.6 instrument.

Computational section: Mixed torsional/low mode conformational searches were carried out by means of the Macromodel 9.9.223 software [25] using OPLS-2005 force field with implicit solvent model for chloroform applying a $42 \mathrm{~kJ} / \mathrm{mol}$ energy window. Geometry reoptimizations (B3LYP/6-31G(d) level in gas phase and B3LYP/TZVP level with PCM solvent model for $\mathrm{CHCl}_{3}$ ) and TDDFT-ECD calculations were performed with Gaussian 09 [26] using various functionals (B3LYP, BH\&HLYP, PBE0) and TZVP basis set for ECD calculations. ECD spectra were generated as the sum of Gaussians [27] with 2100,2400 and $4200 \mathrm{~cm}^{-1}$ half-height width (corresponding to ca. 19, 22 and $38 \mathrm{~nm}$ at $300 \mathrm{~nm}$ ) using dipolevelocity computed rotational strengths. Boltzmann distributions were estimated from the ZPVE-corrected B3LYP/6-31G(d) energies in the gas-phase calculations and from the B3LYP/ TZVP energies in the PCM ones. The MOLEKEL [28] software package was used for visualization of the results.

Bioassay on neuroprotective activity: SH-SY5Y cells were high passages from the American Type Culture Collection and were maintained at $37{ }^{\circ} \mathrm{C}$ in a humidified atmosphere containing $5 \% \mathrm{CO}_{2}$. Cells were pretreated with compounds for $2 \mathrm{~h}$ and then suffered cell injury by treatment with $10 \mu \mathrm{M}$ $\mathrm{A} \beta_{25-35}$ or $100 \mu \mathrm{M} \mathrm{H}_{2} \mathrm{O}_{2}$ for another $24 \mathrm{~h}$; to SH-SY5Y cells, pretreated with compounds before exposed to OGD for $1 \mathrm{~h}$, was added $1 \mathrm{mg} / \mathrm{mL}$ glucose and $10 \%$ serum and cultured for another $24 \mathrm{~h}$ under normal condition. SH-SY5Y cells cultured with glucose under normal condition served as control. Cell viability was evaluated by incubating cells with $0.5 \mathrm{mg} / \mathrm{mL}$ 3-[4,5-dimethylthiazol-2-yl]-2,5-diphenyltetrazolium bromide (MTT) for $3 \mathrm{~h}$ under $5 \% \mathrm{CO}_{2} / 95 \%$ air at $37{ }^{\circ} \mathrm{C}$. After replacement of the medium with $100 \mu \mathrm{L}$ DMSO, absorbance was read at $490 \mathrm{~nm}$. Data were analyzed by one-way analysis of variance (ANOVA) and expressed as means \pm SD with $\mathrm{P}<0.05$ as significance.

2-Phenyl-3,4-dihydro-1,4-benzoxazepin-5(2H)-one (rac-9): To a stirred solution of racemic flavanone ( $r a c-8,10.00 \mathrm{~g}$, $44.63 \mathrm{mmol})$ in TFA $(55 \mathrm{~mL})$, sodium azide $(5.80 \mathrm{~g}$, 
$89.22 \mathrm{mmol}$ ) was added in two parts and the mixture was stirred for $6 \mathrm{~h}$. Cold diethyl ether $(200 \mathrm{~mL})$ was added to the reaction mixture and stirring was continued for $1 \mathrm{~h}$. The precipitated white solid was filtered and refluxed in $180 \mathrm{~mL}$ water for $3 \mathrm{~h}$. After cooling to room temperature, it was refrigerated for $1 \mathrm{~h}$, the resultant precipitate was filtered and washed with cold water. The product $\mathrm{rac}-\mathbf{9}$ was dried and isolated as white powder $(8.23 \mathrm{~g}, 77 \%)$ with mp $127-129{ }^{\circ} \mathrm{C} .{ }^{1} \mathrm{H}$ NMR $(400$ $\left.\mathrm{MHz}, \mathrm{CDCl}_{3}\right) \delta 3.54\left(\mathrm{~m}, 3-\mathrm{H}_{\mathrm{a}}, 1 \mathrm{H}\right), 3.66(\mathrm{~m} \mathrm{3}-\mathrm{Hb}, 1 \mathrm{H}), 5.46$ (dd, $J=9.7$ and $3.6 \mathrm{~Hz}, 2-\mathrm{H}, 1 \mathrm{H}), 7.07$ (d, $J=8.4 \mathrm{~Hz}, 9-\mathrm{H}, 1 \mathrm{H})$, 7.19 (m, $J=7.6 \mathrm{~Hz}, 7-\mathrm{H}, 1 \mathrm{H}), 7.28$ (bs, NH, 1H), 7.36-7.44 (m, $\mathrm{Ph}, 5 \mathrm{H}), 7.50(\mathrm{~m}, J=7.6 \mathrm{~Hz}, 8-\mathrm{H}, 1 \mathrm{H}), 7.85(\mathrm{dd}, J=8.0$ and $1.6 \mathrm{~Hz}, 6-\mathrm{H}, 1 \mathrm{H}) ;{ }^{13} \mathrm{C} \mathrm{NMR}\left(100 \mathrm{MHz}, \mathrm{CDCl}_{3}\right) \delta 46.3(\mathrm{C}-3)$, 85.8 (C-2), 122.4 (C-9), 123.7 (C-7), 125.9 (C-5a), 126.3 (C-2', C-6'), 128.5 (C-4'), 128.7 (C-3', C-5'), 130.9 (C-6), 133.3 (C-8), 139.0 (C-1'), 154.5 (C-9a), 170.9 (C-5); IR (KBr) v: 1462, 1665, 2917, 3075, 3203, $3307 \mathrm{~cm}^{-1}$; HRMS-ESI $(\mathrm{m} / \mathrm{z})$ : $[\mathrm{M}+\mathrm{Na}]^{+}$calcd for $\mathrm{C}_{15} \mathrm{H}_{13} \mathrm{NO}_{2} \mathrm{Na}, 262.0844$; found, 262.0839; Anal. calcd for $\mathrm{C}_{15} \mathrm{H}_{13} \mathrm{NO}_{2}$ (239.09): $\mathrm{C}, 75.30$; $\mathrm{H}$, 5.48; N, 5.85; found: C, 75.28; H, 5.49; N, 5.85.

2-Phenyl-2,3,4,5-tetrahydro-1,4-benzoxazepine (rac-10): To a stirred solution of rac-9 $(8.13 \mathrm{~g}, 33.98 \mathrm{mmol})$ in dry THF $(80 \mathrm{~mL}), 2.0 \mathrm{M}$ lithium aluminium hydride solution in THF was added dropwise $(10 \mathrm{~mL}, 0.76 \mathrm{~g}, 20.03 \mathrm{mmol})$ and the mixture was refluxed for $1.5 \mathrm{~h}$. After cooling to room temperature, ethyl acetate $(5 \mathrm{~mL})$, methanol $(5 \mathrm{~mL})$ and water $(50 \mathrm{~mL})$ were added and the mixture was concentrated under reduced pressure. The residue was extracted with dichloromethane $(3 \times 50 \mathrm{~mL})$. The combined organic layers were washed with water $(20 \mathrm{~mL})$, dried over $\mathrm{MgSO}_{4}$, filtered and concentrated under reduced pressure. The product $\mathrm{rac} \mathbf{- 1 0}$ was isolated as yellow solid (6.12 g, 80\%) with mp 73-74 ${ }^{\circ} \mathrm{C} .{ }^{1} \mathrm{H}$ NMR (400 MHz, $\left.\mathrm{CDCl}_{3}\right)$ $\delta 3.20\left(\mathrm{dd}, J=14.4\right.$ and $\left.10.0 \mathrm{~Hz}, 3-\mathrm{H}_{\mathrm{ax}}, 1 \mathrm{H}\right), 3.37\left(\mathrm{~d}, 3-\mathrm{H}_{\mathrm{eq}}\right.$, $14.4 \mathrm{~Hz}, 1 \mathrm{H}), 3.96$ (d, $\left.J=14.8 \mathrm{~Hz}, 5-\mathrm{H}_{\mathrm{a}}, 1 \mathrm{H}\right), 4.12$ (d, $J=14.8$ $\left.\mathrm{Hz}, 5-\mathrm{H}_{\mathrm{b}}, 1 \mathrm{H}\right), 4.66(\mathrm{~d}, J=10.0 \mathrm{~Hz}, 2-\mathrm{H}, 1 \mathrm{H}), 7.04(\mathrm{~m}, 7-\mathrm{H}$, 8-H, 2H), 7.17 (m, 6-H, 9-H, 2H), 7.31-7.43 (m, Ph, 5H); ${ }^{13} \mathrm{C}$ NMR (100 MHz, $\left.\mathrm{CDCl}_{3}\right) \delta 52.5$ (C-5), 58.9 (C-3), $86.4(\mathrm{C}-2)$, 121.6 (C-9), 123.6 (C-7), 125.8 (C-2', C-6'), 127.7 (C-8), 128.4 (C-3', C-5'), 129.0 (C-4', C-6), 135.6 (C-5a), 140.5 (C-1'), 159.1 (C-9a); IR (KBr) v: 1579, 2935, $3328 \mathrm{~cm}^{-1}$; HRMS-ESI $(m / z):[\mathrm{M}+\mathrm{H}]^{+}$calcd for $\mathrm{C}_{15} \mathrm{H}_{16} \mathrm{NO}, 226.1232$; found, 226.1235; Anal. calcd for $\mathrm{C}_{15} \mathrm{H}_{15} \mathrm{NO}$ (225.11): C, 79.97; $\mathrm{H}$, 6.71 ; N, 6.22; found: C, 80.03; H, 6.76; N, 6.18.

5-Nitro-2-(2-phenyl-2,3-dihydro-1,4-benzoxazepin-4(5H)yl)benzaldehyde (rac-5): To the stirred solution of rac-10 $(1.50 \mathrm{~g}, 6.66 \mathrm{mmol})$ in dry toluene $(25 \mathrm{~mL})$, anhydrous $\mathrm{K}_{2} \mathrm{CO}_{3}$ $(1.85 \mathrm{~g} 13.39 \mathrm{mmol})$ and 2-fluoro-5-nitrobenzaldehyde (1.35 g, $7.98 \mathrm{mmol}$ ) were added and the mixture was refluxed for $8 \mathrm{~h}$. After cooling to room temperature, $\mathrm{K}_{2} \mathrm{CO}_{3}$ was filtered off and toluene was removed under reduced pressure. The residue was purified by column chromatography on silica gel (ethyl acetate/ hexane $4: 1)$ to give $\mathrm{rac}-\mathbf{5}$ as yellow solid (1.77 g, 71\%). Mp $152-156{ }^{\circ} \mathrm{C} ;{ }^{1} \mathrm{H}$ NMR $\left(400 \mathrm{MHz}, \mathrm{CDCl}_{3}\right) \delta 3.63(\mathrm{dd}, J=10.8$ and $\left.13.6 \mathrm{~Hz}, 3-\mathrm{H}_{\mathrm{ax}}, 1 \mathrm{H}\right), 4.04\left(\mathrm{dd}, J=13.6\right.$ and $2.4 \mathrm{~Hz}, 3-\mathrm{H}_{\mathrm{eq}}$, $1 \mathrm{H}), 4.71\left(\mathrm{~d}, J=16.4 \mathrm{~Hz}, 5-\mathrm{H}_{\mathrm{a}}, 1 \mathrm{H}\right), 4.94\left(\mathrm{~d}, J=16.4 \mathrm{~Hz}, 5-\mathrm{H}_{\mathrm{b}}\right.$, $1 \mathrm{H}), 5.29(\mathrm{dd}, J=10.8$ and $2.4 \mathrm{~Hz}, 2-\mathrm{H}, 1 \mathrm{H}), 7.03$ (m, $J=9.6$ Hz, 6-H, 9-H, 2H), 7.13 (m, 8-H, 1H), 7.26 (m, 6"-H, 7-H, 2H), 7.36-7.42 (m, Ph, 5H), 8.17 (dd, $J=9.2 \mathrm{~Hz}$ and $2.8 \mathrm{~Hz}, 5$ "- $\mathrm{H}$, $1 \mathrm{H}), 8.61(\mathrm{~d}, J=2.8 \mathrm{~Hz}, 3$ "- $\mathrm{H}, 1 \mathrm{H}), 9.97$ (s, CHO, $1 \mathrm{H}) ;{ }^{13} \mathrm{C}$ NMR (100 MHz, $\left.\mathrm{CDCl}_{3}\right) \delta 56.1(\mathrm{C}-5), 64.6$ (C-3), 82.7 (C-2), 117.6 (C-6”), 121.0 (C-9), 123.8 (C-7), 124.3 (C-5a), 125.9 (C-2', C-6'), 127.5 (C-2''), 128.1 (C-4”), 128.7 (C-8, C-3”), 129.1 (C-3', C-5'), 129.5 (C-5”), 129.8 (C-4'), 129.8 (C-6), 138.1 (C-1'), 156.8 (C-9a), 158.2 (C-1”), 188.3 (CHO); IR (KBr) v: 1382, 1500, 1681, 1734, $2921 \mathrm{~cm}^{-1}$; HRMS-ESI $(m / z):[\mathrm{M}+\mathrm{Na}]^{+}$calcd for $\mathrm{C}_{22} \mathrm{H}_{18} \mathrm{~N}_{2} \mathrm{O}_{4} \mathrm{Na}, 397.1164$; found, 397.1158; Anal. calcd for $\mathrm{C}_{22} \mathrm{H}_{18} \mathrm{~N}_{2} \mathrm{O}_{4}$ (374.12): C, 70.58; $\mathrm{H}$, 4.85 ; N, 7.48; found: C, 70.59; H, 4.89; N, 7.45.

trans-1,3-Dimethyl-11'-nitro-2'-phenyl-1',2'-dihydro$2 H, 7 b^{\prime} H, 9^{\prime} H$-spiro[pyrimidine-5, $8^{\prime}$-quinolino[1,2d] [1,4]benzoxazepine]-2,4,6(1 H,3H)-trione (rac-trans-7a): To a stirred solution of rac-5 (100 mg, $0.27 \mathrm{mmol})$ in chloroform (5 mL), anhydrous $\mathrm{MgSO}_{4}(150 \mathrm{mg}, 1.25 \mathrm{mmol})$ and 1,3dimethylbarbituric acid (60 $\mathrm{mg}, 0.38 \mathrm{mmol})$ were added and the mixture was refluxed for $4 \mathrm{~h}$. After cooling to room temperature, $\mathrm{MgSO}_{4}$ was filtered off and chloroform was removed under reduced pressure. Water $(10 \mathrm{~mL})$ and dichloromethane $(20 \mathrm{~mL})$ were added and the layers were separated. The aqueous phase was extracted with dichloromethane $(2 \times 10 \mathrm{~mL})$. The combined organic layers were washed with concentrated $\mathrm{NaHCO}_{3}$ solution, dried over $\mathrm{MgSO}_{4}$, filtered and concentrated under reduced pressure. The oily product was triturated with ether to afford rac-trans-7a as yellow solid (131 mg, 96\%) with mp 262-264 ${ }^{\circ} \mathrm{C} .{ }^{1} \mathrm{H}$ NMR (400 MHz, $\left.\mathrm{CDCl}_{3}\right) \delta 2.91$ (s, N-Me, $3 \mathrm{H}), 3.12\left(\mathrm{~d}, J=16.8 \mathrm{~Hz}, 9-\mathrm{H}_{\mathrm{a}}, 1 \mathrm{H}\right), 3.13$ (s, N-Me, 3H), 3.87 $\left(\mathrm{dd}, J=16.4\right.$ and $\left.12.0 \mathrm{~Hz}, 3-\mathrm{H}_{\mathrm{ax}}, 1 \mathrm{H}\right), 4.00(\mathrm{~d}, J=16.8 \mathrm{~Hz}$, $\left.9-\mathrm{H}_{\mathrm{b}}, 1 \mathrm{H}\right), 4.16\left(\mathrm{dd}, J=12.0\right.$ and $\left.3.2 \mathrm{~Hz}, 3-\mathrm{H}_{\mathrm{eq}}, 1 \mathrm{H}\right), 4.81$ (s, $15 \mathrm{a}-\mathrm{H}, 1 \mathrm{H}), 5.13(\mathrm{dd}, J=12.0$ and $3.2 \mathrm{~Hz}, 2-\mathrm{H}, 1 \mathrm{H}), 6.80$ (d, $J$ $=7.6 \mathrm{~Hz}, 19-\mathrm{H}, 1 \mathrm{H}), 6.85(\mathrm{~d}, J=9.2 \mathrm{~Hz}, 5-\mathrm{H}, 1 \mathrm{H}), 7.10(\mathrm{~m}$, 16- H, Ph, 3H), 7.15 (m, 17- H, 1H), 7.30-7.38 (m, 18- H, Ph, $4 \mathrm{H}), 8.08(\mathrm{dd}, J=9.2$ and $2.4 \mathrm{~Hz}, 6-\mathrm{H}, 1 \mathrm{H}), 8.13(\mathrm{~s}, 8-\mathrm{H}, 1 \mathrm{H})$; ${ }^{13} \mathrm{C}$ NMR $\left(100 \mathrm{MHz}, \mathrm{CDCl}_{3}\right) \delta 28.7(\mathrm{Me}), 28.9(\mathrm{Me}), 34.7$ (C-9), 47.3 (C-3) 51.9 (C-10), 71.5 (C-15a), 81.2 (C-2), 109.9 (C-19), 121.5 (C-15b), 123.8 (C-5), 124.7 (C-17), 124.8 (C-6), 125.5 (C-8a), 127.0 (C-2' and C-6'), 128.8 (C-3' and C-5'), 129.1 (C-8), 129.9 (C-18), 132.1 (C-16), 137.6 (C-7), 138.3 (C-1'), 147.6 (C-13), 150.1 (C-19a), 151.7 (C-4a), 167.1 (C-15), 168.9 (C-11); IR (KBr) v: 749, 988, 1326, 1683, 2926 $\mathrm{cm}^{-1}$; HRMS-ESI $(\mathrm{m} / z)$ : $[\mathrm{M}+\mathrm{Na}]^{+}$calcd for $\mathrm{C}_{28} \mathrm{H}_{24} \mathrm{~N}_{4} \mathrm{O}_{6} \mathrm{Na}$, 
535.1594; found, 535.1588; Anal. calcd for $\mathrm{C}_{28} \mathrm{H}_{24} \mathrm{~N}_{4} \mathrm{O}_{6}$ (512.17): C, 65.65; H, 4.72; N, 10.93; found: C, 65.64; H, 4. 70; $\mathrm{N}, 10.95$. $(2 R, 15 \mathrm{a} R)-7 \mathrm{a}$ : retention time $\left(t_{\mathrm{R}}\right) 10.57 \mathrm{~min}$ (Chiralpak IA, hexane/dichloromethane 70:30); HPLC-ECD data in hexane/dichloromethane $70: 30$ as $\lambda_{\max }(\Phi): 378(8.97)$, $368 \mathrm{sh}$ (8.71), 314 (-12.73), $305 \mathrm{sh}$ (-12.73), 284 (2.21), 272 (-1.54), 239 (16.42), $224 \mathrm{sh}(11.27) .(2 S, 15 \mathrm{a} S)-7 \mathbf{a}:$ retention time $\left(t_{\mathrm{R}}\right) 28.73 \mathrm{~min}$ (Chiralpak IA, hexane/dichloromethane 70:30); HPLC-ECD in hexane/dichloromethane $70: 30$ as $\lambda_{\max }$ (Ф): $381 \mathrm{sh}(-4.83), 370$ (-5.03), 314 (7.10), 305 sh (5.68), 286 (-1.24), 270 (0.78), 239 (-9.32), 221 (-11.60).

trans-2,2-Dimethyl-11'-nitro-2'-phenyl-1',2'-dihydro$7 b^{\prime} H, 9^{\prime} H$-s piro $[1,3-d i o x$ an e-5, 8 ' - quinolino [ 1,2 $d][1,4]$ benzoxazepine]-4,6-dione (rac-trans-7b): To the stirred solution of rac-5 (100 mg, $0.27 \mathrm{mmol})$ in chloroform $(5 \mathrm{~mL})$, anhydrous $\mathrm{MgSO}_{4}(150 \mathrm{mg}, 1.25 \mathrm{mmol})$ and Meldrum's acid (54 mg, $0.31 \mathrm{mmol}$ ) were added and the mixture was refluxed for $6 \mathrm{~h}$. After cooling to room temperature, $\mathrm{MgSO}_{4}$ was filtered off and chloroform was removed under reduced pressure. Water $(10 \mathrm{~mL})$ and dichloromethane $(20 \mathrm{~mL})$ were added and the layers were separated. The aqueous phase was extracted with dichloromethane $(2 \times 10 \mathrm{~mL})$. The combined organic layers were washed with concentrated $\mathrm{NaHCO}_{3}$ solution, dried over $\mathrm{MgSO}_{4}$, filtered and concentrated under reduced pressure. The oily product was triturated with ether to afford rac-trans-7b as yellow solid (30 mg, 22\%) with mp $130-134{ }^{\circ} \mathrm{C} .{ }^{1} \mathrm{H}$ NMR (500 $\mathrm{MHz}, \mathrm{CDCl}_{3}$ ) $\delta 1.06$ (s, Me, 3H), 1.62 (s, Me, 3H), 3.19 (d, J= $\left.16.5 \mathrm{~Hz}, 9-\mathrm{H}_{\mathrm{a}}, 1 \mathrm{H}\right), 3.90$ (d, $\left.J=16.5 \mathrm{~Hz}, 9-\mathrm{H}_{\mathrm{b}}, 1 \mathrm{H}\right), 3.95$ (dd, $J$ $=16.5$ and $\left.11.5 \mathrm{~Hz}, 3-\mathrm{H}_{\mathrm{ax}}, 1 \mathrm{H}\right), 4.16(\mathrm{dd} J=16.5 \mathrm{~Hz}$ and 3.2 $\left.\mathrm{Hz}, 3-\mathrm{H}_{\mathrm{eq}}, 1 \mathrm{H}\right), 5.02(\mathrm{~s}, 15 \mathrm{a}-\mathrm{H}, 1 \mathrm{H}), 5.22(\mathrm{dd}, J=11.5 \mathrm{~Hz}$ and $3.2 \mathrm{~Hz}, 2-\mathrm{H}, 1 \mathrm{H}), 6.83(\mathrm{~d}, J=8.0 \mathrm{~Hz}, 19-\mathrm{H}, 1 \mathrm{H}), 6.87$ (d, $J=$ $9.0 \mathrm{~Hz}, 5-\mathrm{H}, 1 \mathrm{H}), 7.12(\mathrm{~m}, 16-\mathrm{H}, 1 \mathrm{H}), 7.22(\mathrm{~m}, 17-\mathrm{H}, 18-\mathrm{H}$, 2H), 7.27-7.35 (m, Ph, 5H), 8.09 (m, 8-H, 6-H, 2H); ${ }^{13} \mathrm{C}$ NMR $\left(100 \mathrm{MHz}, \mathrm{CDCl}_{3}\right) \delta 26.9(\mathrm{Me}), 30.5(\mathrm{Me}), 35.7$ (C-9), 47.2 (C-3), 50.0 (C-10), 70.7 (C-15a), 80.3 (C-2), 105.5 (C-13), 110.0 (C-19), 119.5 (C-8a), 125.1 (C-5), 125.2 (C-17), 125.6 (C-6), 126.7 (C-15b), 127.2 (C-2', C-6'), 128.6 (C-3', C-5'), 129.0 (C-8), 131.1 (C-4'), 131.4 (C-16), 137.3 (C-7), 138.1 (C-1'), 147.7 (C-19a), 152.2 (C-4a), 164.5 (C-15), 168.2 (C-11); IR (KBr) v: 1197, 1322, 1507, 1737, $2925 \mathrm{~cm}^{-1}$; HRMS-ESI $(m / z):[\mathrm{M}+\mathrm{Na}]^{+}$calcd for $\mathrm{C}_{28} \mathrm{H}_{24} \mathrm{~N}_{2} \mathrm{O}_{7} \mathrm{Na}$, 523.1481; found, 523.1475; Anal. calcd for $\mathrm{C}_{28} \mathrm{H}_{24} \mathrm{~N}_{2} \mathrm{O}_{7}$ (500.16): C, 67.19; H, 4.83; N, 5.60; found: C, 67.17; H, 4.86; $\mathrm{N}, 5.59$. $(2 R, 15 \mathrm{a} R)-7 \mathbf{b}$ : retention time $\left(t_{\mathrm{R}}\right) 5.96 \mathrm{~min}$ (Chiralpak IA, hexane/dichloromethane 70:30); HPLC-ECD data in hexane/dichloromethane 70:30 as $\lambda_{\max }(\Phi): 379 \mathrm{sh}(10.62), 368$ (10.90), 312 (-9.79), $303 \mathrm{sh}(-7.89), 279$ (6.49), $261 \mathrm{sh}$ (-3.01), 251 (-3.30), $228(15.44) .(2 S, 15 \mathrm{a} S)-7 \mathbf{b}$ : retention time $\left(t_{\mathrm{R}}\right) 14.09 \mathrm{~min}$ (Chiralpak IA, hexane/dichloromethane 70:30); HPLC-ECD data in hexane/dichloromethane $70: 30$ as $\lambda_{\max }(\Phi)$ :
383 sh (-3.29), $371(-3.71), 311$ (3.16), 302 sh (2.75), 278 $(-2.26), 260 \mathrm{sh}(1.04), 249$ (1.10), 227 (-5.51).

\section{[5-Nitro-2-(2-phenyl-2,3-dihydro-1,4-benzoxazepin-4(5H)-} yl)benzylidene]propanedinitrile $(\mathbf{c})$ : To the stirred solution of rac-5 $(100 \mathrm{mg}, 0.27 \mathrm{mmol})$ in chloroform $(5 \mathrm{~mL})$, anhydrous $\mathrm{MgSO}_{4}(150 \mathrm{mg}, 1.25 \mathrm{mmol})$ and malononitrile $(130 \mathrm{mg}$, $1.97 \mathrm{mmol}$ ) were added and the mixture was refluxed for $10 \mathrm{~h}$. After cooling to room temperature, $\mathrm{MgSO}_{4}$ was filtered off and chloroform was removed under reduced pressure. Water $(10 \mathrm{~mL})$ and dichloromethane $(20 \mathrm{~mL})$ were added and the layers were separated. The aqueous phase was extracted with dichloromethane $(2 \times 10 \mathrm{~mL})$. The combined organic layers were washed with concentrated $\mathrm{NaHCO}_{3}$ solution, dried over $\mathrm{MgSO}_{4}$, filtered and concentrated under reduced pressure. The oily product was triturated with ether to afford $7 \mathbf{c}$ as yellow solid (91 mg, 81\%) with mp $152-156{ }^{\circ} \mathrm{C} .{ }^{1} \mathrm{H}$ NMR (400 MHz, $\left.\mathrm{CDCl}_{3}\right) \delta 3.78(\mathrm{~m}, 3-\mathrm{H}, 2 \mathrm{H}), 4.50\left(\mathrm{~d}, J=15.6 \mathrm{~Hz}, 11-\mathrm{H}_{\mathrm{a}}, 1 \mathrm{H}\right)$, $4.58\left(\mathrm{~d}, J=15.6 \mathrm{~Hz}, 11-\mathrm{H}_{\mathrm{b}}, 1 \mathrm{H}\right), 5.06(\mathrm{dd}, J=10.0 \mathrm{~Hz}$ and 2.4 $\left.\mathrm{Hz}, 3-\mathrm{H}_{\mathrm{eq}}, 1 \mathrm{H}\right), 7.15(\mathrm{~d}, J=8.0 \mathrm{~Hz}, 15-\mathrm{H}, 1 \mathrm{H}), 7.16-7.26(\mathrm{~m}$, 12-H, 13-H, 14-H, 3H), 7.32 (m, 7-H, 1H), 7.41 (m, Ph, 5H), $7.75(\mathrm{~s}, 16-\mathrm{H}, 1 \mathrm{H}), 8.26(\mathrm{dd}, J=9.2 \mathrm{~Hz}$ and $2.6 \mathrm{~Hz}, 7-\mathrm{H}, 1 \mathrm{H})$, $8.85(\mathrm{~d}, J=2.6 \mathrm{~Hz}, 9-\mathrm{H}, 1 \mathrm{H}) ;{ }^{13} \mathrm{C} \mathrm{NMR}\left(100 \mathrm{MHz} \mathrm{CDCl}_{3}\right) \delta$ 59.4 (C-11), 63.2 (C-3), 82.9 (C-2), 84.3 (C-17), $111.8(\mathrm{CN})$, 112.9 (CN), 119.2 (C-15), 121.5 (C-6), 121.9 (C-10), 124.5 (C-13), 125.9 (C-2', C-6', C-9), 128.4 (C-11a), 128.7 (C-7) 128.9 (C-3', C-5', C-14), 129.2 (C-4'), 129.9 (C-12), 138.2 (C-8), 141.2 (C-1'), 156.9 (C-16), 158.2 (C-15a), 158.5 (C-5) IR (KBr) v: 759, 1222, 1335, 1488, 2227, $2923 \mathrm{~cm}^{-1}$; HRMS-ESI $(\mathrm{m} / \mathrm{z}):[\mathrm{M}+\mathrm{Na}]^{+}$calcd for $\mathrm{C}_{25} \mathrm{H}_{18} \mathrm{~N}_{4} \mathrm{O}_{3} \mathrm{Na}$, 445.1277; found, 445.1271; Anal. calcd for $\mathrm{C}_{28} \mathrm{H}_{18} \mathrm{~N}_{4} \mathrm{O}_{3}$ (422.14): C, 71.08; H, 4.29; N, 13.26; found: C, 71.05; H, 4.30; $\mathrm{N}, 13.25$. First eluting enantiomer of $7 \mathbf{c}$ : retention time $\left(t_{\mathrm{R}}\right)$ $21.41 \mathrm{~min}$ (Chiralpak IA, hexane/dichloromethane 80:20); HPLC-ECD data in hexane/dichloromethane 80:20 as $\lambda_{\max }(\Phi)$ : 348 (-4.21), 279 (3.84), 252 sh (1.62), 223 (2.04). Second eluting enantiomer of $7 \mathbf{c}$ : retention time $\left(t_{\mathrm{R}}\right) 21.41 \mathrm{~min}$ (Chiralpak IA, hexane/dichloromethane 80:20); HPLC-ECD data in hexane/dichloromethane $80: 20$ as $\lambda_{\max }(\Phi): 356$ (3.97), 281 (-3.48), $250 \mathrm{sh}(-1.32)$.

\section{Supporting Information}

\section{Supporting Information File 1}

Spectroscopic data and details of calculations.

Structures and populations of the in vacuo and PCM solvent model conformers, cartesian coordinates of $\mathbf{7 b}-\mathbf{d}$,

${ }^{1} \mathrm{H},{ }^{13} \mathrm{C}$ NMR and IR spectra are disclosed in this file.

[http://www.beilstein-journals.org/bjoc/content/ supplementary/1860-5397-10-272-S1.pdf] 


\section{Acknowledgements}

Sándor Antus thanks the Hungarian National Research Foundation (OTKA K81701) for financial support. The financial support implemented in the frame of the ÉAOP-1.1.3-12-20120026 is acknowledged. This work was partially supported by the European Union and the European Social Fund through the project Supercomputer, the national virtual lab (grant no.: TAMOP-4.2.2.C-11/1/KONV-2012-0010).

\section{References}

1. Kuribara, H. Jpn. J. Pharmacol. 1994, 64, 273-280. doi:10.1254/jjp.64.273

2. Kamei, K.; Maeda, N.; Nomura, K.; Shibata, M.; Katsuragi-Ogino, R.; Koyama, M.; Nakajima, M.; Inoue, T.; Ohno, T.; Tatsuoka, T. Bioorg. Med. Chem. 2006, 14, 1978-1992. doi:10.1016/j.bmc.2005.10.046

3. Tani, Y.; Ogata, A.; Koyama, M.; Inoue, T. Eur. J. Pharmacol. 2010, 649, 218-223. doi:10.1016/j.ejphar.2010.09.013

4. Nolan, J. C.; Stephens, D. J.; Proakis, A. G.; Leonard, C. A.; Johnson, D. N.; Kilpatrick, B. F.; Foxwell, M. H.; Yanni, J. M. Agents Actions 1989, 28, 53-61. doi:10.1007/BF02022980

5. Sleevi, M. C.; Cale, A. D., Jr.; Gero, W. T.; Jaques, L. W.; Welstead, W. J.; Johnson, A. F.; Kilpatrick, B. F.; Demian, I.; Nolan, J. C.; Jenkins, H. J. Med. Chem. 1991, 34, 1314-1328. doi:10.1021/jm00108a012

6. Brewer, M. D.; Burgess, M. N.; Dorgan, R. J. J.; Elliott, R. L.; Mamalis, P.; Manger, B. R.; Webster, R. A. B. J. Med. Chem. 1989, 32, 2058-2062. doi:10.1021/jm00129a007

7. Meth-Cohn, O.; Suschitzky, H. Adv. Heterocycl. Chem. 1972, 14, 211-278. doi:10.1016/S0065-2725(08)60954-X

8. Meth-Cohn, O. Adv. Heterocycl. Chem. 1996, 65, 1-37. doi:10.1016/S0065-2725(08)60294-9

9. Mátyus, P.; Éliás, O.; Tapolcsányi, P.; Polonka-Bálint, Á.; Halász-Dajka, B. Synthesis 2006, 2625-2639. doi:10.1055/s-2006-942490

10. Földi, Á. A.; Ludányi, K.; Bényei, A. C.; Mátyus, P. Synlett 2010, 2109-2113. doi:10.1055/s-0030-1258536

11. Dunkel, P.; Túrós, D.; Bényei, A.; Ludányi, K.; Mátyus, P. Tetrahedron 2010, 66, 2331-2339. doi:10.1016/j.tet.2010.02.014

12. Murarka, S.; Deb, I.; Zhang, C.; Seidel, D. J. Am. Chem. Soc. 2009, 131, 13226-13227. doi:10.1021/ja905213f

13. Kang, Y. K.; Kim, S. M.; Kim, D. Y. J. Am. Chem. Soc. 2010, 132 11847-11849. doi:10.1021/ja103786c

14. Cao, W.; Liu, X.; Wang, W.; Lin, L.; Feng, X. Org. Lett. 2011, 13, 600-603. doi:10.1021/ol1028282

15. Zhou, G.; Liu, F.; Zhang, J. Chem. - Eur. J. 2011, 17, 3101-3104. doi:10.1002/chem.201100019

16. Chen, L.; Zhang, L.; Lv, J.; Cheng, J.-P.; Luo, S. Chem. - Eur. J. 2012 , 18, 8891-8895. doi:10.1002/chem.201201532

17. Mori, K.; Ehara, K.; Kurihara, K.; Akiyama, T. J. Am. Chem. Soc. 2011, 133, 6166-6169. doi:10.1021/ja2014955

18. Litkey, G.; Patonay, T. Acta Chim. Hung. 1983, 114, 47-56.

19. Zhu, J.; Ye, Y.; Ning, M.; Mándi, A.; Feng, Y.; Zou, Q.; Kurtán, T.; Leng, Y.; Shen, J. ChemMedChem 2013, 8, 1210-1223. doi:10.1002/cmdc.201300144

20. Gulyás-Fekete, G.; Murillo, E.; Kurtán, T.; Papp, T.; Illyés, T.-Z.; Drahos, L.; Visy, J.; Agócs, A.; Turcsi, E.; Deli, J. J. Nat. Prod. 2013, 76, 607-614. doi:10.1021/np3007827
21. Gao, H.; Liu, W.; Zhu, T.; Mo, X.; Mándi, A.; Kurtán, T.; Li, J.; Ai, J.; Gu, Q.; Li, D. Org. Biomol. Chem. 2012, 10, 9501-9506. doi:10.1039/c2ob26757h

22. Jiang, C.-S.; Guo, X.-J.; Gong, J.-X.; Zhu, T.-T.; Zhang, H.-Y.; Guo, Y.-W. Bioorg. Med. Chem. Lett. 2012, 22, 2226-2229. doi:10.1016/j.bmcl.2012.01.103

23. Crispo, J. A. G.; Piché, M.; Ansell, D. R.; Eibl, J. K.; Tai, I. T.; Kumar, A.; Ross, G. M.; Tai, T. C. Biochem. Biophys. Res. Commun. 2010, 393, 773-778. doi:10.1016/j.bbrc.2010.02.079

24. Bastianetto, S.; Yao, Z.-X.; Papadopoulos, V.; Quirion, R. Eur. J. Neurosci. 2006, 23, 55-64. doi:10.1111/j.1460-9568.2005.04532.x

25. MacroModel; Schrödinger LLC: New York, 2012, http://www.schrodinger.com/MacroModel.

26. Gaussian 09, Revision B.01; Gaussian, Inc.: Wallingford, CT, 2010.

27. Stephens, P. J.; Harada, N. Chirality 2010, 22, 229-233. doi:10.1002/chir.20733

28. MOLEKEL, version 5.4; Swiss National Supercomputing Centre: Manno, Switzerland, 2009.

\section{License and Terms}

This is an Open Access article under the terms of the Creative Commons Attribution License (http://creativecommons.org/licenses/by/2.0), which permits unrestricted use, distribution, and reproduction in any medium, provided the original work is properly cited.

The license is subject to the Beilstein Journal of Organic Chemistry terms and conditions:

(http://www.beilstein-journals.org/bjoc)

The definitive version of this article is the electronic one which can be found at: doi:10.3762/bjoc. 10.272 